\title{
The Effect of e-Aminocaproic Acid on Biochemical Changes in the Development of the Cellular Slime Mould Dictyostelium discoideum
}

\author{
By M. J. NORTH* AND ANNE J. CAMPBELL $\dagger$ \\ Department of Biology, University of Essex, Colchester, Essex $\mathrm{CO}_{4}{ }_{3} \mathrm{SQ}$
}

(Received I9 December I975)

\begin{abstract}
SUMMARY
$\epsilon$-Aminocaproic acid (EACA) inhibited the development of Dictyostelium discoideum strain AX2 after the aggregation stage. Biochemical changes that occurred early in development (loss of cellular protein, RNA and carbohydrate; increase in the specific activity of $\beta$ - $N$-acetylglucosaminidase, $\alpha$-mannosidase, threonine deaminase and leucine aminopeptidase) were not affected by concentrations of EACA which blocked development ; but biochemical changes that occurred later (synthesis of carbohydrate, increase in the specific activity of UDP-glucose pyrophosphorylase) were inhibited. Spores from fruiting bodies formed in the presence of low concentrations of EACA were larger, more spherical and less able to survive heat treatment than spores from fruiting bodies of control (no EACA) cells.
\end{abstract}

\section{INTRODUCTION}

Certain $\omega$-aminocarboxylic acids affect the development of the cellular slime mould Dictyostelium discoideum (North \& Ashworth, 1976). These agents allow aggregation to proceed apparently normally, but, above a particular concentration, they prevent further morphological development. The effect is observed only with strains capable of axenic growth. At lower concentrations, the inhibitors allow development to proceed after aggregation, but a variety of abnormal morphological structures are formed, dependent on the concentration. If fruiting body construction does take place, there is a reduction in the number of spores per fruiting body.

During normal development in $D$. discoideum, a number of well-characterized changes occur in the levels of various macromolecules and enyzmes (Loomis, 1975). Many take place at specific times during differentiation and are considered to be developmentally regulated. It was therefore of interest to determine whether some of these changes were affected by inhibitors that apparently allow development to aggregation to proceed normally, but which prevent or adversely affect further development. In this paper we describe the effects of one particular $\omega$-aminocarboxylic acid, the antifibrinolytic agent (Ablondi et al., 1959) $\epsilon$-aminocaproic acid.

\section{METHODS}

Chemicals. Glucose 6-phosphate dehydrogenase (in ammonium sulphate) and phosphoglucomutase (in ammonium sulphate) were from Boehringer Corp., Mannheim, West Germany. Cemulsol NPT-I2 was from Rhone Progil, Courbevoie, France. $p$-Nitro-2acetamido-2-deoxy- $\beta$-D-glucopyranoside and $p$-nitrophenyl- $\alpha$-D-mannopyranoside were

* Present address : Biochemistry Laboratories, University of Stirling, Stirling FK9 4LA.

$\dagger$ Present address : Department of Biochemistry, University of Adelaide, Adelaide, South Australia, Australia. 
from Koch-Light. $p$-Aminomethylbenzoic acid (PAMBA), a gift from VEB Arzneimittlelwerk, Dresden, East Germany, was supplied in solution (I0 $\mathrm{mg} \mathrm{ml}^{-1}$ in $0.9 \% \mathrm{NaCl}$ ). All other biochemicals were from Sigma; and chemicals were of the highest purity available from Fisons Scientific Apparatus, Loughborough, Leicestershire.

Strain. Dictyostelium discoideum strain AX2 (ATCC24397) was used throughout this study.

Growth and differentiation. Myxamoebae were grown in shaken cultures in axenic medium lacking added carbohydrate (Watts \& Ashworth, 1970), or with Klebsiella aerogenes as described by North \& Ashworth (1976). Washed amoebae, suspended in water, were deposited on Millipore filters and allowed to develop as described by Hames \& Ashworth (1974a), except that the temperature of incubation was $24^{\circ} \mathrm{C}$. To allow for the dilution of the pad diluting fluid (PDF; Garrod \& Ashworth, $1972 ; 1.6 \mathrm{ml}$ per support pad) by the deposition of the myxamoebal suspension $(0.5 \mathrm{ml})$, the concentration of substances added to the PDF was I.3I times greater than the final concentration required.

Determination of heat stability of spores. Spores were harvested from mature fruiting bodies into Io mM-potassium phosphate buffer pH 6.5 (Cotter \& Raper, I966) as described by North \& Ashworth (1976). The spores were counted with a haemocytometer and then diluted with potassium phosphate buffer to approximately $10^{4}$ spores $\mathrm{ml}^{-1}$. Portions of suspension ( $\mathrm{I} \mathrm{ml}$ ) were incubated at $45^{\circ} \mathrm{C}$ in prewarmed $125 \times 12 \mathrm{~mm}$ test-tubes and removed, at intervals, into ice. Serial dilutions were prepared and the viable spore count determined by plating $0 . \mathrm{I} \mathrm{ml}$ of the original and diluted suspensions with $K$. aerogenes on SM agar (Sussman, 1966). Plaques were counted after incubation at $22{ }^{\circ} \mathrm{C}$ for 3 or 4 days, and again after 7 days.

Determination of mean spore volume. Spores were harvested as described previously (North \& Ashworth, 1976) into $0.4 \% \mathrm{NaCl}$, to give a density of approximately $10^{6}$ spores $\mathrm{ml}^{-1}$, and the mean cell volume was determined using a Coulter model P64 Size Distribution Analyzer, standardized with DVB Latex beads.

Cell extract preparation for enzyme assays. For most of the enzyme assays, cells from Millipore filters were harvested into cold distilled water ; but for threonine deaminase assays, a cold aqueous solution of pyridoxal phosphate $\left(20 \mu \mathrm{g} \mathrm{ml}^{-1}\right)$ was used, and for UDPglucose pyrophosphorylase and 6-phosphogluconate dehydrogenase assays, the cells were harvested into cold $\mathrm{O} \cdot \mathrm{I} \mathrm{M}-\mathrm{N}$-tris(hydroxymethyl)methylglycine (tricine)/ $\mathrm{NaOH}, \mathrm{pH} 7 \cdot 6$. All suspensions were stored at $-20^{\circ} \mathrm{C}$. Extracts were prepared by sonication at a peak amplitude of $9 \mu \mathrm{m}$ in iced water using an MSE I50 W ultrasonic disintegrator ; $4 \times 15 \mathrm{~s}$ bursts were used for suspensions of cells up to early culmination, and $8 \times 15 \mathrm{~s}$ bursts for later developmental stages. Extracts were assayed within $\mathrm{I} h$ of preparation. For assays of UDPglucose pyrophosphorylase and 6-phosphogluconate dehydrogenase, cells were lysed by rapid trituration in the detergent Cemulsol NPT- 12 at a final concentration of $0.15 \%$; assays were performed immediately after cell lysis.

Enzyme assays. $\beta$ - $N$-Acetylglucosaminidase (EC. 3.2.1.30; 2-acetamido-2-deoxy- $\beta$-Dglucoside acetamidodeoxyglucohydrolase) was assayed at $35^{\circ} \mathrm{C}$ as described by Loomis (I069), except that the final concentration of the substrate was $5 \mathrm{~mm}$ and that of the sodium acetate/acetic acid buffer (pH 5) was 20 mM. $\alpha$-Mannosidase (EC. 3.2. I .24; $\alpha$-D-mannoside mannohydrolase) was assayed at $35^{\circ} \mathrm{C}$ as described by Loomis (1970). Leucine aminopeptidase (EC. 3.4.II.I) was assayed at $30^{\circ} \mathrm{C}$ as described by Firtel \& Brackenbury (1972). Developmental threonine deaminase (EC. 4.2 . I I 6 ; L-threonine hydro-lyase, deaminating) was assayed at $25^{\circ} \mathrm{C}$ as outlined by Pong \& Loomis (1973). UDP-glucose pyrophosphorylase (EC. 2.7.7.9; UTP : $\alpha$-D-glucose I-phosphate uridylyltransferase) was assayed at $37^{\circ} \mathrm{C}$ as described by Newell \& Sussman (1969). 6-Phosphogluconate dehydrogenase (EC. 
I . I. I .44; 6-phospho-D-gluconate :NADP + 2-oxidoreductase, decarboxylating) was assayed spectrophotometrically at $37^{\circ} \mathrm{C}$ at the same time as the extract was assessed for UDPglucose pyrophosphorylase activity; a final volume of I $\mathrm{ml}$ contained $100 \mu \mathrm{mol}$ tricine/ $\mathrm{NaOH}, \mathrm{pH} 7.6,5.6 \mathrm{mg} \mathrm{NADP}, 4 \mu \mathrm{mol} \mathrm{MgCl}_{2}$ and I $\mu \mathrm{mol}$ 6-phosphogluconate (modified from Edmundson \& Ashworth, 1972).

A unit of enzyme activity is expressed as nmol product formed per min at the incubation temperature ; specific enzyme activity is expressed as units of enzyme activity per mg protein of the extract used.

Other assays. Cellular protein, RNA and DNA levels were estimated using suspensions of cells washed from Millipore filters with water. Material precipitated by the addition of trichloroacetic acid (final concentration $10 \%$, w/v) was collected by centrifuging, washed with $10 \%(\mathrm{w} / \mathrm{v})$ trichloroacetic acid and resuspended in $5 \%(\mathrm{w} / \mathrm{v})$ trichloroacetic acid. The suspension was incubated at $90{ }^{\circ} \mathrm{C}$ for $30 \mathrm{~min}$ and the insoluble material was collected by centrifuging. The hydrolysate was used for RNA and DNA determinations; the pellet was dissolved in $2 \mathrm{M}-\mathrm{NaOH}$, and protein was estimated in the resulting solution by the method of Lowry et al. (I95I) using bovine albumin (Sigma; fraction V) as standard. RNA was estimated by the orcinol method (Mejbaum, 1939) using ribose as standard and DNA as described by Hames, Weeks \& Ashworth (I972) using calf thymus DNA (Sigma; type I) as standard. Relative cellular levels of protein and RNA were calculated using the finding of Hames (1972) that the cellular DNA level remains constant during development on Millipore filters.

Total carbohydrate levels were determined by the anthrone method of Hassid \& Abraham (I957) in extracts prepared by sonication as described for enzyme assays. Trehalose was determined as described by Hames \& Ashworth (I974b) using trehalase purified from Neurospora crassa. Relative levels of carbohydrate and trehalose were calculated on the basis of a constant cellular DNA level.

\section{RESULTS}

\section{Effect of EACA on levels of macromolecules}

During the development of Dictyostelium discoideum, there are changes in the total carbohydrate content which can be ascribed to two processes : an early rapid breakdown of myxamoebal carbohydrate, as glycogen (Hames et al., 1972); and a later synthesis of developmental saccharides (Hames \& Ashworth, I974a, $b$ ). As the extent of these two processes differs depending on the growth conditions of the myxamoebae, the effect of EACA on the degradation and synthesis of carbohydrate during development was evaluated by using myxamoebae grown under different conditions.

To determine the effect of EACA on the breakdown of carbohydrate during development, myxamoebae were grown in axenic medium containing glucose; such cells have high levels of carbohydrate (more than I $\mathrm{mg}$ glycogen $/ \mathrm{Io}^{8}$ cells) and during their differentiation there is a net loss of total carbohydrate (Hames \& Ashworth, 1974a). This loss was not affected by EACA and after $26 \mathrm{~h}$ on filters, cells incubated with 50 mm-EACA contained $20 \%$ less carbohydrate than control (no EACA) cells (results not shown).

To determine the effect of EACA on the synthesis of total carbohydrate during development, myxamoebae were grown in axenic medium lacking sugar; such cells contain very small amounts of carbohydrate (less than $0.1 \mathrm{mg}$ glycogen $/ 10^{8}$ cells) and during differentiation show a net increase in total carbohydrate (Hames \& Ashworth, 1974a). However when such cells were allowed to develop in the presence of increasing EACA concentrations, the final structures contained decreasing levels of carbohydrate (Fig. I) suggesting that 


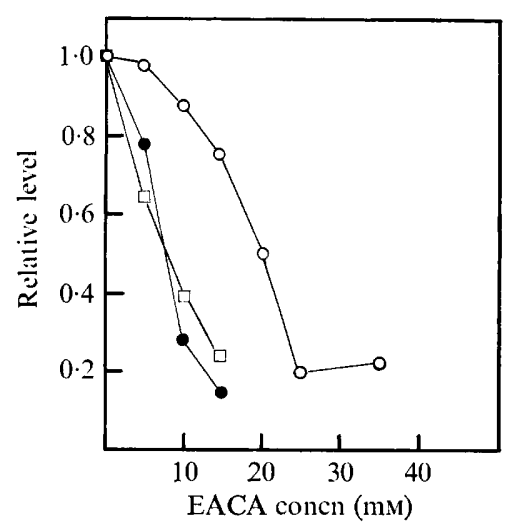

Fig. 1. Effect of EACA concentration on the total carbohydrate (anthrone-positive material) and trehalose content of axenically-grown cells incubated on Millipore filters for $28 \mathrm{~h}$. The developmental stage was as described previously (North \& Ashworth, 1976). Total carbohydrate (O), trehalose (@), spores formed ( $\square$ ). All values are relative to those for control (no EACA) cells.

EACA inhibited carbohydrate synthesis during differentiation. This effect was observed with concentrations of EACA that allowed development to proceed after aggregation, and even when visual observation suggested that fruiting body construction was normal. A similar decrease in the level of total carbohydrate during development in the presence of increasing EACA concentrations was found with bacterially-grown cells (results not shown); in the absence of EACA, the total carbohydrate level increases during development. The effect of EACA on the level of one specific developmental carbohydrate, trehalose, was examined; normally trehalose is synthesized later in development (Hames \& Ashworth, $1974 b$ ). Cells were grown in axenic medium with no added sugar and incubated on filters with different concentrations of EACA ; as with the total carbohydrate, the level of trehalose was lower in cells incubated with higher concentrations of EACA (Fig. I). The number of spores formed also decreases with increasing EACA concentration (North \& Ashworth, I976), but despite this the level of trehalose per spore was reduced, e.g. with Io mM-EACA, the spore trehalose content was estimated to be $70 \%$ of that in control spores.

The effect of EACA on two other types of macromolecule was also studied. Immediately after myxamoebae are deposited on to Millipore filters, there are large and rapid decreases in the cellular levels of protein and RNA (Hames \& Ashworth, I974a). The presence of $50 \mathrm{~mm}-\mathrm{EACA}$ did not significantly affect either the rate or the extent of loss of protein or RNA.

\section{Effect of EACA on changes in enzyme activities}

Many enzyme activities are known to change during the development of $D$. discoideum (Loomis, 1975). In a number of cases, and, in particular, with enzymes whose specific activities increase during the initial period of development, the change in activity is dependent on the manner in which the cells are grown (Quance \& Ashworth, 1972). In axenicallygrown cells, there is little significant change in the specific activity of a number of these enzymes (Quance \& Ashworth, 1972), and so in order to examine the effect of EACA, myxamoebae were grown with $K$. aerogenes. The effect of $50 \mathrm{mM}$-EACA on the changes in activity of five enzymes is shown in Fig. 2. In no case was an effect of EACA due to an effect on the enzyme activity in the assay system. Increases in the activities of the four enzymes, $\beta$ - $N$-acetylglucosaminidase, $\alpha$-mannosidase, leucine aminopeptidase and threonine 

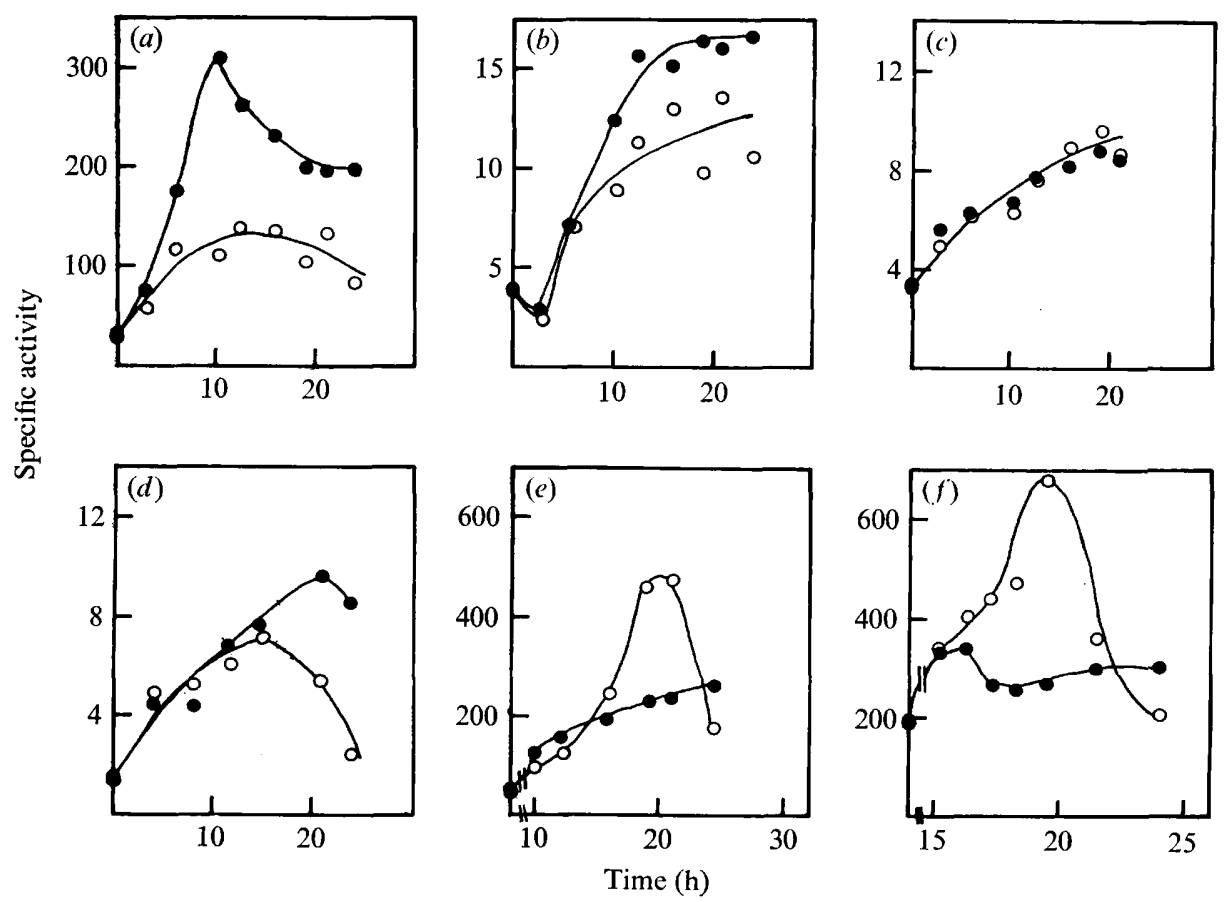

Fig. 2. Effect of EACA on changes in the specific activity of $(a) \beta-N$-acetylglucosaminidase, $(b) \alpha-$ mannosidase, $(c)$ leucine aminopeptidase, $(d)$ threonine deaminase, $(e, f)$ UDP-glucose pyrophosphorylase, during incubation on Millipore filters in the absence $(\bigcirc)$ and presence $(O)$ of $50 \mathrm{~mm}$ EACA. $(a-e)$ Bacterially-grown cells, $(f)$ axenically-grown cells

deaminase, which take place within the first five hours of incubation on filters, were not inhibited by EACA. The activities of the first two enzymes were, in fact, enhanced by its presence, and EACA apparently prevented a decrease in threonine deaminase at a later time. The increase of UDP-glucose pyrophosphorylase activity, which occurs at a later stage of development, was inhibited by EACA in both bacterially-grown (Fig. $2 e$ ) and axenicallygrown (Fig. $2 f$ ) cells. There was a decrease in the maximum level of activity with increasing EACA concentration (Fig. 3) that paralleled the decrease in total carbohydrate (Fig. I). The presence of 6-phosphogluconate dehydrogenase activity in extracts may affect the observed UDP-glucose pyrophosphorylase activity under the conditions of the assay (Edmundson \& Ashworth, I972), but since the level of this activity was not affected by EACA (Fig. 3) the difference in UDP-glucose pyrophosphorylase levels could not be accounted for in this way. Thus the inhibition must represent a lack of increase in the level of UDP-glucose pyrophosphorylase activity.

\section{Effects of $\beta$-alanine and PAMBA}

To examine the specificity of the action of EACA, the effect of two other $\omega$-aminocarboxylic acids was tested. $\beta$-Alanine is a homologue of EACA which does not inhibit postaggregation development even at $50 \mathrm{~mm}$ (North \& Ashworth, 1976), while the antifibrinolytic agent $p$-aminomethylbenzoic acid (PAMBA; Donner \& Housková, 1967) blocks development in the same way as EACA but at lower concentrations (North \& Ashworth, 


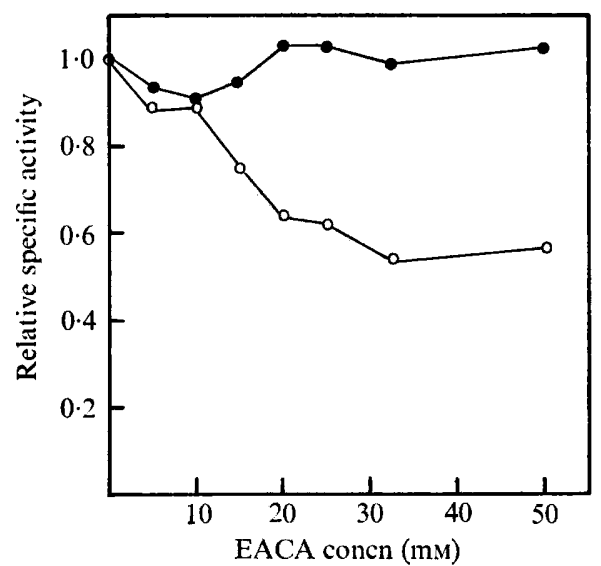

Fig. 3

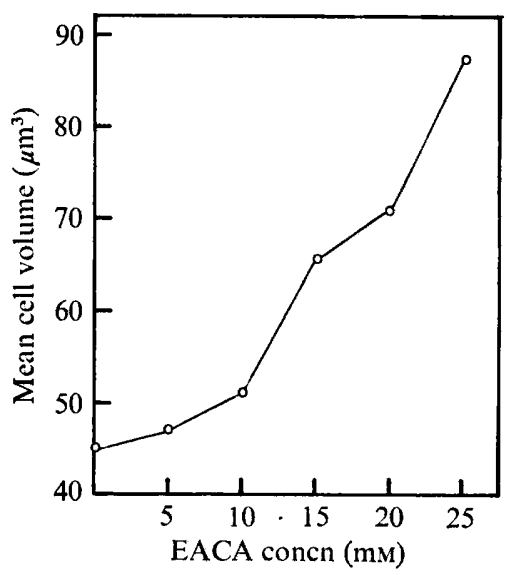

Fig. 4

Fig. 3. Effect of EACA concentration on the specific activity of UDP-glucose pyrophosphorylase $(O)$ and of 6-phosphogluconate dehydrogenase (O) during the development of axenically-grown myxamoebae. The specific activity for UDP-glucose pyrophosphorylase represents the maximum level and is expressed relative to the maximum level of control (no EACA) cells ; that for 6-phosphogluconate dehydrogenase is the level after $17 \mathrm{~h}$ incubation on filters and is expressed relative to the level in control cells. The final structures formed were as described previously (North \& Ashworth, 1976).

Fig. 4. Effect of EACA concentration on the mean cell volume of spores. Axenically-grown cells were incubated on Millipore filters, and spores harvested after $42 \mathrm{~h}$. The cells developed to the stages described previously (North \& Ashworth, 1976).

I976). Under the conditions used in these experiments, 2.5 to 3 mM-PAMBA produced complete inhibition after aggregation.

At $50 \mathrm{mM}, \beta$-alanine had very little effect on the increase in activity of $\beta$ - $N$-acetylglucosaminidase, $\alpha$-mannosidase or UDP-glucose pyrophosphorylase. Unlike EACA, it did not enhance the increase in the activity of any enzyme, and its effect on UDP-glucose pyrophosphorylase was variable but small (o to $25 \%$ inhibition). It also caused a small decrease (approximately $25 \%$ ) in the total carbohydrate level of apparently mature fruiting bodies.

PAMBA completely inhibited the increase in UDP-glucose pyrophosphorylase activity at concentrations above $2.5 \mathrm{mM}$, but had no effect on the increases in $\beta$ - $N$-acetylglucosaminidase or $\alpha$-mannosidase. The carbohydrate content of cells incubated on filters decreased with increasing PAMBA concentration; the magnitude of the change was similar to that produced by EACA concentrations which affected morphology to the same extent.

\section{Effect of EACA on properties of spores}

The effect of EACA on the level of carbohydrate in fruiting bodies formed in the presence of low concentrations of the inhibitor posed the question of whether the spores that were produced were defective in any way. Microscopic observations revealed that incubation with EACA produced a change in spore shape. Spores from fruiting bodies formed by AX2 cells incubated with no addition to the PDF were elliptical ; but as the EACA concentration in the PDF was increased, so the spores appeared more spherical, although they did retain their refractility. The mean spore volume also increased with increasing EACA concentration (Fig. 4), but, at concentrations above $20 \mathrm{mM}$, part of this increase could be accounted 


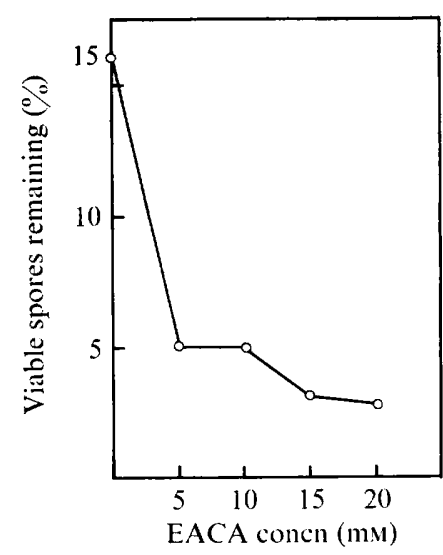

Fig. 5

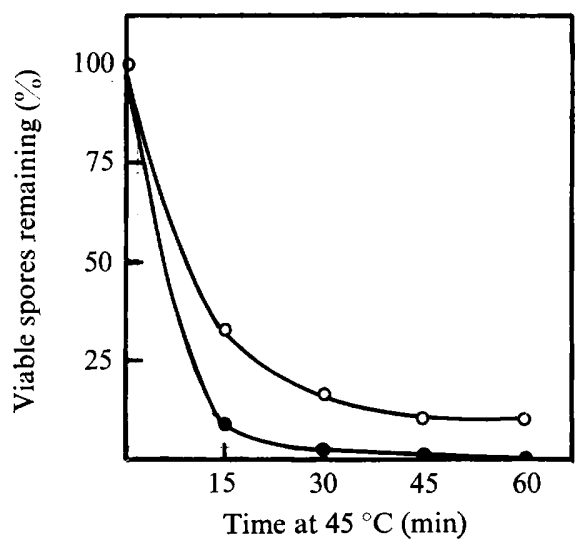

Fig. 6

Fig. 5. Effect of EACA concentration on the heat stability of spores. Spores were harvested from axenically-grown cells incubated on filters for $42 \mathrm{~h}$. Values represent the number of viable spores remaining after $30 \mathrm{~min}$ incubation at $45^{\circ} \mathrm{C}$ as a percentage of the number present initially. Values are those for plaques formed after 7 days.

Fig. 6. Time course of the loss of viability of spores from fruiting bodies formed in the absence (O) and presence $(0)$ of $15 \mathrm{~mm}$-EACA. Spores were harvested from axenically-grown cells incubated on filters for $42 \mathrm{~h}$. Values are those for plaques formed after 7 days.

for by the presence of a few (less than $10 \%$ of total cell number) apparently undifferentiated non-refractile cells in the spore mass. At concentrations of EACA below $20 \mathrm{~mm}$, the cells were all refractile.

The spores formed after incubation with EACA were tested for heat stability. Even those spores formed during development in the presence of low concentrations of EACA ( 5 to I5 mM) were much less able to survive incubation at $45^{\circ} \mathrm{C}$ than were control (no EACA) spores (Figs. 5 and 6). Identical results were obtained with bacterially-grown cells. The heat stability of control spore populations varied between experiments (e.g. 16 to $70 \%$ survival after $30 \mathrm{~min}$ incubation at $45^{\circ} \mathrm{C}$ of spores from axenically-grown cells), but in all cases spores formed in the presence of EACA were considerably less stable than the corresponding controls. Incubation at $45^{\circ} \mathrm{C}$ led not only to a loss of viability but also to an apparent delayed germination of the survivors. Spores that were not treated at $45^{\circ} \mathrm{C}$ all gave rise to the maximum number of visible plaques within 4 days, but the maximum number of plaques formed by a population of heat-treated spores was not observed until after 6 to 7 days incubation at $22{ }^{\circ} \mathrm{C}$. The proportion of spores displaying delayed germination was greater with spores formed in the presence of EACA.

Spores from fruiting bodies formed in the presence of PAMBA were spherical and were less heat-stable than control cells. However the loss of heat stability was not as great as with EACA. Spores formed in the presence of $\beta$-alanine were elliptical. Although there was some loss of heat stability in spores formed after incubation with $20 \mathrm{mM}-\beta$-alanine, the loss was considerably less than with EACA, even at $5 \mathrm{mM}$.

\section{DISCUSSION}

Since EACA and other $\omega$-aminocarboxylic acids which affect development in $D$. discoideum have no apparent effect on aggregation, and since EACA is still able to block postaggregation development when cells are first exposed to it after $8 \mathrm{~h}$ incubation on Millipore 
filters, it was concluded (North \& Ashworth, I976) that these inhibitors must have an effect at a specific time during development, presumably during the period between 8 and $\mathbf{1} 2 \mathrm{~h}$ after the start of incubation when aggregated cells begin to show morphological changes. The results presented here are consistent with this conclusion, since, in general, those processes that begin early in the developmental phase were unaffected by EACA, while those taking place at later times were inhibited. The only exception to this was the enhancement of $\beta$ - $N$-acetylglucosaminidase activity which occurred even after 5 h incubation (Fig. $2 a$ ).

UDP-glucose pyrophosphorylase is a key enzyme in the carbohydrate metabolism of developing cells of $D$. discoideum (Franke \& Sussman, 1973; Gustafson, Kong \& Wright, 1973). A decrease in the level of activity of this enzyme might be expected to lead to a decreased ability of the cells to synthesize end-product saccharides, and so it is possible that the inhibition of the increase in activity and the lower carbohydrate levels in the EACAtreated cells are related.

At present, we can only speculate on the mechanism by which EACA leads to a decreased UDP-glucose pyrophosphorylase activity. Since EACA apparently acts at a specific stage, it is unlikely that its effect is due to a general metabolic inhibition. Brackenbury \& Sussman (I975) have proposed a model for the regulation of UDP-glucose pyrophosphorylase in which synthesis of the enzyme is dependent on cell-cell contact. It is possible that EACA interferes with the signalling system by which cells relay to the intracellular synthetic machinery that they have come into contact with each other.

The decrease of UDP-glucose pyrophosphorylase activity and of carbohydrate production would provide an explanation for some of the observed morphological changes and alterations in the spore properties. Decreased cellulose production by stalk cells would lead to a decreased ability of the weakened stalk to support the spore mass; a folding-over of the spore mass has been observed (North \& Ashworth, 1976). A decrease in the production of the cell-wall polysaccharides and of trehalose by the spores may well be the cause of their changes in shape and volume and their reduced ability to survive heat treatment.

It is unlikely, however, that all the changes resulting from incubation with EACA are due to its effect on the increase in UDP-glucose pyrophosphorylase activity and carbohydrate metabolism. Further investigations are in progress to establish the primary mode of action.

We wish to express our thanks to Professor J. M. Ashworth, in whose laboratory this work was performed, for his interest and helpful criticism, to Mrs Irene Hames for perform: ing the spore volume determination, and to Miss Leonie Smith for excellent technical assistance. We thank the Science Research Council for financial support. M. J. N. was a Science Research Council Postdoctoral Research Fellow.

\section{REFERENCES}

Ablondi, F. B., Hagan, J. J., Phillips, M. \& De Renzo, E. C. (1959). Inhibition of plasmin, trypsin and the streptokinase-activated fibrinolytic system by $\epsilon$-aminocaproic acid. Archives of Biochemistry and Biophysics 82, I 53-160.

Brackenbury, R. \& Sussman, M. (1975). Mutant of Dictyostelium discoideum defective in cell contact regulation of enzyme expression. Cell 4, 347-352.

CotTer, D. A. \& RAPER, K. B. (I966). Spore germination in Dictyostelium discoideum. Proceedings of the National Academy of Sciences of the United States of America 56, 880-887.

DoNnER, L. \& Houskoví, J. (1967). On the action mechanism of some fibrinolysis inhibitors. Thrombosis et diathesis haemorrhagica 18, 439-446.

EDmundson, T. D. \& AsHworTH, J. M. (1972). 6-Phosphogluconate dehydrogenase and the assay of uridine diphosphate glucose pyrophosphorylase in the cellular slime mould Dictyostelium discoideum. Biochemical Journal 126, 593-600. 
Firtel, R. A. \& BrackenbuRY, R. W. (1972). Partial characterization of several protein and amino acid metabolizing enzymes in the cellular slime mould Dictyostelium discoideum. Developmental Biology 27, 307-32I.

Franke, J. \& Sussman, M. (1973). Accumulation of uridine diphosphoglucose pyrophosphorylase in Dictyostelium discoideum via preferential synthesis. Journal of Molecular Biology 81, I73-I 85 .

Garrod, D. R. \& AshworTh, J. M. (1972). Effect of growth conditions on development of the cellular slime mould, Dictyostelium discoideum. Journal of Embryology and Experimental Morphology 28, 463-479.

Gustafson, G. L., KonG, W. Y. \& WRIGHT, B. E. (I973). Analysis of uridine diphosphate-glucose pyrophosphorylase synthesis during differentiation in Dictyostelium discoideum. Journal of Biological Chemistry 248, 5188-5196.

HAMES, B. D. (1972). The metabolic control of development in the cellular slime mould Dictyostelium discoideum. Ph.D. thesis, University of Leicester.

HAMES, B. D. \& AshworTh, J. M. (1974a). The metabolism of macromolecules during the differentiation of myxamoebae of the cellular slime mould Dictyostelium discoideum containing different amounts of glycogen. Biochemical Journal 142, 30I-315.

HAMES, B. D. \& AshwORTH, J. M. (1974b). The control of saccharide synthesis during development of myxamoebae of Dictyostelium discoideum containing differing amounts of glycogen. Biochemical Journal I42, 317-325.

Hames, B. D., Weeks, G. \& Ashworth, J. M. (1972). Glycogen synthetase and the control of glycogen synthesis in the cellular slime mould Dictyostelium discoideum during cell differentiation. Biochemical Journal 126, 627-633.

Hassid, W. Z. \& Abraham, S. (1957). Chemical procedures for analysis of polysaccharides. In Methods in Enzymology, vol. 3, pp. 34-50. Edited by S. P. Colowick and N. O. Kaplan. New York and London : Academic Press.

Loomis, W. F. (1969). Acetylglucosaminidase, an early enzyme in the development of Dictyostelium discoideum. Journal of Bacteriology 97, I 149 -I 54.

Loomis, W. F. (1970). Developmental regulation of $\alpha$-mannosidase in Dictyostelium discoideum. Journal of Bacteriology 103, 375-381.

Loomis, W. F. (1975). Dictostelium discoideum : a Developmental System. New York : Academic Press.

Lowry, O. H., Rosebrough, N. J., Farr, A. L. \& Randall, R. J. (I95I). Protein measurement with the Folin phenol reagent. Journal of Biological Chemistry 193, 265-275.

Mejbaum, W. (1939). Über die Bestimmung kleiner Pentosemengen imbesondere in Derivaten der Adenylsäure. Hoppe-Seyler's Zeitschrift für physiologische Chemie 258, I I 7-I 20.

Newell, P. C. \& Sussman, M. (I969). Uridine diphosphate glucose pyrophosphorylase in Dictyostelium discoideum. Journal of Biological Chemistry 244, 2990-2995.

North, M. J. \& AshworTh, J. M. (1976). Inhibition of the development of the cellular slime mould Dictyostelium discoideum by $\omega$-aminocarboxylic acids. Journal of General Microbiology 96, 63-75.

Pong, S. S. \& Loomis, W. F. (1973). Replacement of an anabolic threonine deaminase by a catabolic threonine deaminase during development of Dictyostelium discoideum. Journal of Biological Chemistry 248, $4867-4873$.

QuANCE, J. \& Ashworth, J. M. (1972). Enzyme synthesis in the cellular slime mould Dictyostelium discoideum during the differentiation of myxamoebae grown axenically. Biochemical Journal 126, 609-615.

Sussman, M. (1966). Biochemical and genetic methods in the study of cellular slime mould development. In Methods in Cell Physiology, vol. 2, pp. 397-410. Edited by D. M. Prescott. New York: Academic Press.

WATrs, D. J. \& AshwORTH, J. M. (1970). Growth of myxamoebae of the cellular slime mould Dictyostelium discoideum in axenic culture. Biochemical Journal 119, I7I-I 74. 